\title{
HARTA BERSAMA DAN KEDUDUKAN ANAK YANG BERCERAI DARI PERNIKAHAN SIRRI: KAJIAN TENAGA KERJA WANITA (TKW) DI DESA BUNDER KECAMATAN SUSUKAN KABUPATEN CIREBON
}

\section{Treasure Together and Position of Spirited Children from Wedding Sirri: Students of Women Labor (TKW) in Bunder Village, Susukan District, Cirebon Regency}

\begin{abstract}
Abdul Wahid ${ }^{1}$
ABSTRACT

Sirri marriage is an alternative to the impasse of society whose desire to marry has peaked and filled the inner space, but is unable to carry on marriage because of obstacles and economy. Sirri marriage is a marriage that is carried out in accordance with the conditions of marriage in Islam, but is not registered in the Office of Religious Affairs (KUA) or by the Marriage Registration Officer (PPN). It is called sirri because it is done secretly, closed, secret, or secretly without the publication in the form of a reception. Although in terms of Islamic law sirri marriage does
\end{abstract}

\footnotetext{
Lecturer, Legal Studies, Faculty of Law, University Nahdlatul Ulama Cirebon,
} Jalan Sisingamangaraja Nomor 33, Cirebon. abdulwahid.lawyercrb@gmail.com 
not result in marriage being null or invalid, provided that it meets the marriage principle, namely: the existence of prospective husbands and prospective wives, guardians, witnesses, contracts ( (jjāb and qabūl), and dowry. But many people of Desa Bunder, Susukan District, Cirebon Regency, married Sirri. This resulted in the illegality of a marriage according to the law in Indonesia, this sirri marriage did not have the legality of formal state law. The Indonesian legal system is not familiar with the term sirri marriage and does not specifically regulate it in a law, so the effect of the sirri marriage has not recorded the marriage as a legal event, and has an impact on the sharing of shared property when the marriage is broken (divorce) and also to the position his son.

Keywords: joint treasure, position of child, divorce, sirri marriage

\section{PENDAHULUAN}

Dalam Islam, terdapat akad pernikahan yang sah dan ada yang sebaliknya. Hal ini disebabkan akad yang sah adalah akad yang dilaksanakan dengan syarat-syarat dan rukun-rukun yang lengkap, selari dengan panduan Syarak. Sebaliknya akad yang tidak sah adalah akad yang dilaksanakan tidak bersesuaian dengan syarat-syarat serta rukun-rukun pernikahan. Akan tetapi di Desa Bunder terdapat fenomena pernikahan yang dilaksanakan hanya dengan hukum Syarak sahaja, khususnya dalam rumah tangga Tenaga Kerja Wanita (TKW). Pernikahan ini sering disebut dengan istilah pernikahan sirri (sembunyi), iaitu pernikahan tanpa bukti yang sah menurut undang-undang.

Pernikahan adalah sesuatu yang suci dan setiap pasangan suami isteri sentiasa mendambakan rumah tangga yang sakinah, mawaddah dan warahmah. Ketika keadaan rumah tangga dalam keadaan rukun, umumnya harta kekayaan bersama itu berperanan sebagai pelengkap kebahagiaan. Namun, apabila rumah tangga mengalami keadaan yang tidak lagi stabil, maka kemungkinan timbulnya perselisihan dan pertengkaran yang cukup besar. Hal inilah yang menyebabkan berlakunya konflik rumah tangga apabila tidak dapat mempertahankan kelangsungan pernikahan sirri dan menjamin serta melindungi ikatan pernikahan tersebut serta akibat hukum lain yang mungkin timbul di kemudian hari. Hal ini termasuklah isu pembahagian harta bersama dalam rumah tangga yang bercerai dalam kalangan rumah tangga TKW di Desa Bunder Kecamatan Susukan Kabupaten Cirebon. 
Kajian ini dijalankan di Desa Bunder Kecamatan Susukan Kabupaten Cirebon oleh kerana lokasi ini strategik untuk dijadikan kawasan kajian dan terdapat pasangan suami isteri yang berkahwin secara sirri yang majoriti pencarian isteri bekerja di luar negeri sebagai TKW. Seharusnya yang bertanggungjawab mencari nafkah dalam rumah tangga adalah suami, akan tetapi sebaliknya isteri yang bekerja untuk memenuhi keperluan hidup rumah tangga.

Bagi menghuraikan lagi perbincangan kajian, beberapa persoalan kajian dirumuskan sepertimana berikut:

a) Bagaimanakah pembahagian harta bersama dalam rumah tangga TKW yang bercerai dari pernikahan sirri di Desa Bunder Kecamatan Susukan Kabupaten Cirebon?

b) Bagaimanakah kedudukan anak dalam dalam rumah tangga TKW yang bercerai dari pernikahan sirri di Desa Bunder Kecamatan Susukan Kabupaten Cirebon?

\section{METODOLOGI KAJIAN}

Kajian ini menggunakan pendekatan undang-undang sosial (social legal approach). Pendekatan undang-undang sosial dimaksudkan sebagai penerapan dan kajian hubungan antara aspek perundangan dengan aspek bukan perundangan dalam kalangan masyarakat. Penelitian hukum yang sosiologi mengikuti pola penelitian ilmu-ilmu sosial khususnya sosiologi sehingga disebut sebagai socio legal research. Penelitian hukum sosiologi atau empirikal hendak mengadakan pengukuran terhadap perundangan tertentu mengenai keberkesanannya, maka definisi-definisi operasional diambil daripada peraturan tersebut. ${ }^{2}$

Menurut Abdul Kadir Muhammad, kajian socio legal adalah tentang pelaksanaan atau implementasi ketentuan perundangan dan kontrak yang sebenar pada setiap peristiwa hukum tertentu yang berlaku dalam kalangan masyarakat untuk mencapai tujuan yang telah ditentukan. ${ }^{3}$

Spesifikasi penelitian ini menggunakan jenis deskriptif analitik, iaitu mengambil kesimpulan umum daripada permasalahan yang dibincangkan, iaitu berkaitan pembahagian harta bersama dalam rumah tangga TKW yang

\footnotetext{
2 Soerjono Soekanto, Pengantar Penelitian Hukum (Jakarta: UI Press, 2010), 53.

3 Abdulkdir Muhammad, Hukum dan Penelitian Hukum (Bandung: Citra Aditya Bakti, 2004), 134.
} 
bercerai dari pernikahan sirri di Desa Bunder, di samping memberikan gambaran, menulis dan melaporkan suatu objek atau suatu peristiwa.

Penelitian ini menggunakan pendekatan deskriptif analitik yang mengumpulkan informasi mengenai status gejala yang ada, iaitu gejala keadaan yang apa adanya ketika kajian dijalankan. Penelitian deskriptif analitik juga merupakan gambaran yang bersifat sistematik dan tepat mengenai fakta-fakta serta ciri khas tertentu yang terdapat dalam suatu objek penelitian. Dengan kata lain, penulis dapat mendeskripsikan suatu gejala, peristiwa, dan kejadian yang berlaku di lapangan. Oleh yang demikian, penulis menggunakan sumber primer, sekunder dan tertier dalam melengkapkan kajian ini. ${ }^{4}$

Metode analisis data dalam kajian ini menggunakan analisis data secara kualitatif, iaitu analisis yang dilakukan dengan memahami dan menyusun data yang diperolehi secara sistematik, kemudian dirumuskan. Rumusan yang diambil menggunakan pendekatan deduktif, iaitu dengan cara berfikir yang mendasari hal-hal yang bersifat umum kemudian dirumuskan secara khusus.

\section{KERANGKA TEORI}

Teori yang digunakan dalam penelitian ini adalah teori fungsionalisme struktural yang diperkenalkan oleh Talcott Parson, dengan melihat realiti sosial sebagai hubungan sistem; sistem masyarakat, yang berada dalam keseimbangan, yakni kesatuan yang terdiri daripada bahagian-bahagian yang saling bergantungan, sehingga perubahan satu bahagian dilihat menyebabkan perubahan lain dari sistem. ${ }^{5}$ Teori fungsionalisme struktural tertumpu kepada struktur masyarakat dan antara hubungan pelbagai struktur yang dilihat saling mendukung ke arah keseimbangan yang dinamik.

Adapun teori hukum Islam yang digunakan dalam penelitian adalah teori "al-sulh" iaitu perjanjian perdamaian antara kedua-dua belah pihak (suami dan isteri) apabila mereka berselisih.

\section{HARTA BERSAMA RUMAH TANGGA TKW DI DESA BUNDER KECAMATAN SUSUKAN KABUPATEN CIREBON}

Dalam kitab-kitab fiqh tradisional, harta bersama bermaksud harta kekayaan yang dihasilkan oleh suami isteri selama mereka diikat oleh tali pernikahan, atau dengan perkataan lain disebutkan bahawa harta bersama itu adalah harta

\footnotetext{
4 Suharsimi Arikunto,Manajemen Penelitian (Jakarta: Rineka Citra, 2005), 45.

5 Ritzer George \& Douglas J. Goodman, Teori Sosiologi Modern, ed. ke-6 (Jakarta: Kencana Prenada Media Group, 2011), 117.
} 

Kajian Tenaga Kerja Wanita (TKW) di Desa Bunder Kecamatan Susukan Kabupaten Cirebon

yang dihasilkan dengan shirkah (percampuran harta) antara suami dan isteri sehingga berlakunya percampuran harta antara satu dengan yang lain dan tidak dapat dibezakan lagi. ${ }^{6}$

Harta bersama dalam Islam diqiyaskan dengan shirkah 'abdan mufāwadah yang bererti perkongsian tenaga dan perkongsian tidak terbatas. ${ }^{7}$ Penulis mendapati bahawa masih ramai dalam kalangan masyarakat di Desa Bunder Kecamatan Susukan Kabupaten Cirebon yang mengamalkan pernikahan secara sirri. Terdapat beberapa alasan yang menjadi sandaran kepada pernikahan sirri sebagaimana berikut:

Pertama, budaya seks bebas (free sex) dan kumpul kebo (Bahasa Jawa) yang dilarang sama sekali di Indonesia. Oleh yang demikian, pernikahan adalah institusi yang memiliki fungsi paling asas dan sah untuk memenuhi keperluan ini. Di dalamnya tersirat pengertian bahawa dengan berkahwin secara sirri adalah perbuatan yang semula dianggap dosa dan mengakibatkan perasaan bersalah itu berubah kedudukannya menjadi perbuatan yang sah dan dibenarkan menurut agama.

Kedua, permintaan mereka atas faktor ekonomi sehinggakan pernikahan tersebut perlu disegerakan dan sekadar menurut rukun dan syarat dalam Islam sahaja. Disebabkan masalah ekonomi tersebut, maka pernikahan secara Islam adalah pilihan terbaik dan lebih ekonomi, serta sangat membantu. Akad pernikahan berlandaskan hukum Syarak cukup sekadar dilakukan di hadapan ulama atau kiai sebagai penghulu nikahnya.

Undang-Undang Pernikahan Nomor 1 Tahun 1974 tentang pernikahan menyebutkan bahawa setiap pernikahan perlu didaftarkan. Salah satu daripada bentuk pernikahan yang disembunyikan dalam kalangan masyarakat Indonesia adalah pernikahan sirri. Nikah sirri adalah pernikahan yang dilakukan secara sembunyi, ada yang didaftarkan tetapi disembunyikan dari masyarakat dan ada juga yang tidak didaftarkan kepada Petugas Pencatat Nikah (PPN) dan tidak didaftarkan di Kantor Urusan Agama (KUA). Nikah sirri lazimnya disebut sebagai nikah di bawah tangan. ${ }^{8}$

6 Abdul Manan, Masalah Hukum Perdata Islam di Indonesia, Cetakan Kedua (Jakarta, Kencana, 2006), 109.

7 Tihami \& Sobari Sahrani, Fikih Munakahat Kajian Fikih Lengkap, Ct. 3 (Jakarta, Rajawali Pers, 2013), 179.

8 Mardani, Hukum Perkawinan Islam di Dunia Islam Modern (Yogjakarta: Graha Ilmu, 2011), 17. 
Pernikahan antara suami isteri yang dilakukan secara sah akan membawa kesan perundangan sepertimana berikut: ${ }^{9}$

a) Timbulnya hubungan yang sah antara suami dan isteri. Oleh yang demikian, mereka mempunyai hak dan kewajipan yang perlu dilaksanakan untuk menegakkan rumah tangga.

b) Wujudnya harta dalam pernikahan. Suami isteri yang terikat dalam pernikahan yang sah, akan mempunyai harta, sama ada yang diperolehi sebelum pernikahan mahupun selama tempoh pernikahan. Peraturan terhadap harta kekayaan pernikahan dijelaskan pada Pasal 35 hingga Pasal 37 Undang-Undang Pernikahan No. 1 Tahun 1974.

c) Terbentuknya hubungan antara ibu bapa dan anaknya hasil daripada pernikahan yang sah. Peraturan selanjutnya dijelaskan di bawah Pasal 45 hingga Pasal 49 Undang-Undang No. 1 Tahun 1974.

Pernikahan secara sirri sememangnya mempengaruhi kemaslahatan harta. Hal ini kerana identiti pernikahan tersebut kabur dan tidak dapat dibuktikan melalui buku nikah. Oleh yang demikian, identiti anak yang dilahirkan juga tidak jelas, sehinggakan apabila ibu bapanya meninggal dunia, si anak begitu sukar untuk mendapatkan harta pusaka daripada mereka. Hal ini termasuklah bagi seseorang isteri yang ingin menuntut haknya sebagai ahli waris yang sah melalui perkahwinan sirri, sama ada sebagai isteri pertama atau kedua atau seterusnya. ${ }^{10}$

Di dalam Kamus Besar Bahasa Indonesia, istilah pernikahan dimaksudkan sebagai peristiwa mahupun hasil dari suatu peristiwa di mana dua orang mengikat janji untuk hidup bersama. Dari perspektif sosiologi, pernikahan merupakan ikatan zahir dan batin antara seorang lelaki dengan seorang perempuan dalam suatu hubungan suami isteri.. ${ }^{11}$

Fenomena ini yang berlaku di Desa Bunder khususnya dalam rumah tangga TKW menerusi pernikahan sirri yang mana pihak isteri bekerja di luar negeri menghasilkan harta dalam keluarga. Pernikahan yang berlandaskan sakinah, mawaddah dan warahmah terkandas di tengah jalan disebabkan beberapa faktor:

9 Keputusan Fatwa Majelis Ulama Indonesia Nomor: 4/MUNAS VII/MUI/8/2005 tentang Perkawinan Beda Agama.

10 Ali Uraidy, MH, 'Perkawinan Sirri dan Akibat Hukumnya Ditinjau Dari UndangUndang No. 1 Tahun 1974,' Jurnal Ilmiah FENOMENA, vol. 10, no. 2 (2012): 982-998.

11 Indriyani, Sri Sutanti, Sosiologi Suatu Kajian Hidup Bermasyarakat (Sukoharjo: Ghalia Indonesia, 2007), 44. 
a) Suami yang ditinggalkan di rumah melakukan hubungan dengan perempuan lain.

b) Suami atau isteri ingin menguasai seluruh harta yang dihasilkan selama pernikahan.

c) Isteri tidak menghormati dan melayani suami kerana isteri yang merasa mempunyai harta dalam keluarga.

d) Terdapat faktor lain dari pihak ketiga yang menjadi penyebab perceraian rumah tangga TKW dari pernikahan sirri.

Akibat daripada perceraian tersebut, maka berlakunya polemik dan perselisihan berkaitan pembahagian harta bersama dalam rumah tangga TKW yang bercerai dari pernikahan sirri di Desa Bunder.

Apabila ditinjau dari sahnya pernikahan menurut Undang-Undang Nomor 1 Tahun 1974 ditentukan dalam Pasal 2 ayat (1) yang menentukan, bahawa:

"Pernikahan adalah sah apabila dilakukan menurut hukum masing-masing agamanya dan kepercayaannya itu."

Berdasarkan ketentuan di atas, dapat diketahui bahawa undang-undang pernikahan menitikberatkan sahnya pernikahan pada dua unsur, iaitu undangundang negara dan hukum Syarak. Pernikahan perlu dilaksanakan sesuai dengan syarat dan prosedur yang ditentukan oleh undang-undang negara dan hukum Syarak. Hal ini bermaksud sekiranya pernikahan yang dilangsungkan hanya menepati kehendak undang-undang negara sahaja tanpa menitikberatkan garis panduan Syarak, maka pernikahan tersebut dianggap sebagai tidak sah, dan demikian juga sebaliknya. ${ }^{12}$

Kesan yang jelas dapat dilihat ialah apabila harta yang diperolehi sepanjang tempoh pernikahan sirri (sama ada melalui suami mahupun isteri) tidak boleh dinilai sebagai harta aset mahupun liabiliti dalam keluarga. Harta ini sepatutnya dibahagi bersama apabila berlakunya perceraian. Oleh itu, tidak hairanlah jika timbulnya konflik rumah tangga sehinggakan asas kesamarataan tidak tercapai antara kedua-dua belah pihak.

Oleh yang demikian, pendekatan bagi menyelesaikan polemik dan perselisihan tersebut adalah melalui teori fungsionalisme struktural yang diperkenalkan oleh Talcott Parsons, bahawa pernikahan sebagai sebuah realiti sosial yang sentiasa berintegrasi dengan kehidupan masyarakat. Dalam teori fungsionalisme struktural, dijelaskan bahawa masyarakat terintegrasi atas

12 Wahyono Darmabrata, Tinjauan UU No. 1 Tahun 1974 (Gitama Jaya, Jakarta, 2003), 101. 
dasar kesepakatan dari para anggotanya akan nilai-nilai kemasyarakatan tertentu yang memiliki kemampuan mengatasi perbezaan sehingga masyarakat dilihat sebagai suatu sistem yang berfungsi secara bersepadu dalam suatu keseimbangan. Dengan demikian, masyarakat adalah merupakan kumpulan sistem-sistem sosial yang berhubungan dan saling bergantungan antara satu sama lain. Parsons kemudian mengembangkan apa yang disebut sebagai "imperatif berfungsi" yang dikenali sebagai skema AGIL. Suatu sistem perlu memiliki empat fungsi agar mampu bertahan (survive) dengan lebih lama, iaitu: ${ }^{13}$

a) Adaptation; fungsi ini amat penting di mana sistem perlu beradaptasi dengan menangani situasi luaran yang serius dan mampu menyesuaikan diri dengan persekitaran serta menyesuaikan persekitaran bagi keperluannya.

b) Goal Attainment; pencapaian tujuan sangat penting, di mana sistem perlu mampu mendefinisikan dan mencapai tujuan.

c) Integration; sebuah sistem perlu mengatur dan menjaga antara hubungan bahagian-bahagian yang menjadi komponennya, selain mengatur dan mengelola ketiga-tiga fungsi (AGIL).

d) Latency; sistem perlu berfungsi sebagai pemelihara pola dan memperbaiki motivasi pola-pola individu dan budaya.

Parsons secara khusus tidak menyoroti tentang pernikahan. Akan tetapi perlu difahami bahawa pernikahan merupakan sebahagian daripada sistem sosial. Dalam konteks pernikahan sirri di Desa Bunder, khususnya pernikahan dalam rumah tangga TKW masih berada dalam ketegangan. Sistem yang sedia ada masih belum mampu memenuhi keperluan masyarakat. Sedangkan kehidupan masyarakat sangat heterogen dan bersifat pluralistik. Dengan kenyataan seperti ini, maka seharusnya sistem sosial yang sedia ada mampu mengatur setiap komponen dan elemen yang ada dalam sistem tersebut bagi mencapai tujuannya.

Sedangkan dalam Islam tiada panduan secara khusus tentang kaedah pembahagian harta bersama (Bahasa Jawa: gono-gini). Islam hanya menjelaskan secara umum dalam menyelesaikan masalah bersama, di antaranya adalah; pembahagian harta gono-gini tergantung kepada suami dan isteri. Kesepakatan ini dijelaskan di dalam al-Quran dengan istilah “al-sulh", iaitu perjanjian perdamaian antara kedua-dua belah pihak (suami dan isteri) setelah mereka berselisih. Allah SWT berfirman di dalam al-Quran:

$\overline{13}$ Ritzer George \& Douglas J. Goodman, Teori Sosiologi Modern, 117. 
Harta Bersama dan Kedudukan Anak Yang Bercerai Dari Pernikahan Sirri: Kajian Tenaga Kerja Wanita (TKW) di Desa Bunder Kecamatan Susukan Kabupaten Cirebon

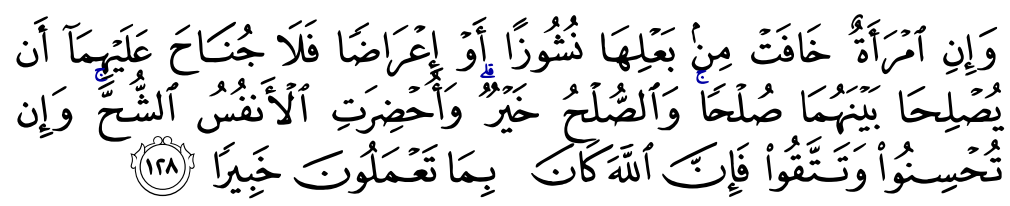

"Dan jika seorang wanita khuatir akan nusyuz atau sikap tidak acuh dari suaminya. Maka tidak mengapa bagi keduaduanya mengadakan perdamaian yang sebenar-benarnya, dan perdamaian itu lebih baik (bagi mereka) walaupun manusia itu menurut tabiatnya kikir dan jika kamu bergaul dengan isterimu secara baik dan memelihara dirimu (dari nusyuz dan sikap tidak acuh), maka sesungguhnya Allah Maha Mengetahui apa yang kamu kerjakan."

(Surah al-Nisā', 4: 128)

Ayat di atas menerangkan tentang langkah perdamaian yang perlu diambil oleh suami isteri apabila mereka berselisih. Lazimnya di dalam perdamaian tersebut, ada pihak yang perlu merelakan hak-haknya. Dalam ayat di atas, isteri merelakan hak-haknya kepada suami demi perdamaian antara keduaduanya. Hal ini dikuatkan dengan sabda Rasulullah SAW:

$$
\text { الصلح جائز بين المسلمين إلا صلحا أحل حر اما أو حرم حلالا }
$$

"perdamaian dibolehkan di antara kaum Muslimin, kecuali perdamaian yang mengharamkan yang halal dan perdamaian yang menghalalkan yang haram." 14

Salah satu tujuan hidup bersama dalam negara demokrasi ini adalah seperti yang diperuntukkan di bawah Pasal 28D ayat 1 UUD 1945, iaitu:

"(1) Setiap orang berhak atas pengakuan, jaminan, perlindungan, dan kepastian hukum yang adil serta perlakuan yang sama di hadapan hukum."

Berdasarkan peruntukan ini, seharusnya sistem sosial yang ada mampu mengatasi dan mengatur keperluan masyarakat seperti keperluan atas penerimaan atau pengakuan, keperluan akan jaminan perlindungan, keperluan akan kepastian undang-undang yang adil dan juga keperluan akan perlakuan yang sama. Berkaitan dengan persoalan harta bersama dalam rumah tangga TKW yang bercerai dari pernikahan sirri, dalam kenyataannya nilai-nilai,

14 Hadis riwayat Abū Dāwud, Ibn Mājah dan al-Tirmidhī. Lihat Imām al-Shawkān̄̄, Nayl al-Awțār (Bayrūt: Dār al-Kutub al-'Alamiyyah, t.t.), no. hadis 2325. 
norma-norma atau aturan undang-undang yang berlaku tidak sepenuhnya mampu memenuhi keperluan sosial masyarakatnya. Sehingga individu yang ada dalam sistem tersebut tentunya berusaha untuk mengatur dan mengatasinya dengan pelbagai alternatif untuk menghubungkan dan menyesuaikan sesuatu bahagian dengan bahagian yang lain. Bentuknya dan amalan perundangan berkaitan pembahagian harta bersama rumah tangga TKW yang bercerai dari pernikahan sirri di Desa Bunder tidak menggunakan sistem pembahagian secara rata terhadap harta yang dihasilkan setelah pernikahannya, bahkan kesepakatan sebagaimana berikut:

a) Apabila suami lebih banyak bekerja dan menghasilkan harta berbanding isteri, maka bahagian suami sama besar dengan bahagian isteri dikira dari jumlah aset dalam keluarga;

b) Apabila isteri lebih banyak bekerja dan menghasilkan harta berbanding suami, maka bahagian isteri lebih besar berbanding bahagian suami dikira dari jumlah aset dalam keluarga;

c) Apabila suami atau isteri bekerja dan menghasilkan harta yang sama banyak, maka bahagian isteri lebih besar berbanding bahagian suami.

Sistem pembahagian harta bersama di atas di luar nafkah anak dan harta bawaan yang diperoleh suami atau isteri sebelum melaksanakan pernikahan sirri tidak menjadi bahagian dari harta bersama. Sistem pembahagian yang berlaku dalam kalangan masyarakat Desa Bunder ini lebih efektif dan adil yang tidak menimbulkan perselisihan yang berterusan. Pelaksanaan sistem ini berperanan melindungi dan memberikan jaminan terhadap isteri dan anak. Hal ini selaras dengan teori pembahagian harta bersama menurut hukum Islam sebagaimana termaktub di dalam al-Quran Surah An-Nisa ayat 128.

\section{KEDUDUKAN ANAK DARI PERNIKAHAN SIRRI DI DESA BUNDER KECAMATAN SUSUKAN KABUPATEN CIREBON}

Perintah untuk mendaftarkan setiap pernikahan adalah perintah yang bersifat wajib (imperatif), yang bertujuan untuk mendapatkan pengesahan dan pengiktirafan negara bahawa suatu pernikahan itu telah berlaku, sehingga semua kesan perundangan dan hal-hal yang berkaitan dengan pernikahan tersebut dapat diselesaikan melalui institusi rasmi negara, iaitu institusi kehakiman..$^{15}$

15 M. Anshary MK, Kedudukan Anak dalam Perspektif Hukum Islam dan Hukum Nasional (Bandung: CV Mandar Maju, 2014), 133. 
Kajian Tenaga Kerja Wanita (TKW) di Desa Bunder Kecamatan Susukan Kabupaten Cirebon

Suatu pernikahan yang mengabaikan perintah Pasal 2 ayat(2) UU Pernikahan tersebut akan memberikan kesan kepada status pernikahan itu sendiri, iaitu tidak mempunyai sandaran perundangan (no legal force) sebagaimana bunyi Pasal 6 ayat (2) Kompilasi Hukum Islam:

"bahawa pernikahan yang dilakukan di luar pengawasan Pegawai Pencatat Nikah tidak mempunyai kekuatan hukum."

Oleh sebab itu, setiap pernikahan yang tidak didaftarkan kepada Pegawai Pencatat Nikah akan dikira sebagai pernikahan tidak pernah wujud (never existed), dan menyebabkan ia tidak boleh dilindungi oleh mana-mana perundangan (no legal protect). ${ }^{16}$ Apabila seseorang anak yang dilahirkan itu memerlukan akta kelahiran untuk suatu urusan penting seperti mendaftar persekolahan misalnya, maka tidak boleh di“bin”kan dengan nama bapanya. Hal ini berikutan mereka tidak memiliki sebarang bukti tentang pernikahan dalam bentuk akta, memandangkan asas untuk mengeluarkan akta kelahiran anak adalah berdasarkan akta nikah ibu bapa mereka.

Hak asasi bagi seseorang anak berbeza jika dibandingkan dengan orang dewasa. Hal ini kerana si anak sejak masih dalam kandungan, dilahirkan, tumbuh dan berkembang sehingga dewasa, masih dalam keadaan tergantung, dan belum bebas. Bahkan si anak memerlukan perhatian khusus sama ada dalam penjagaan gizi, kesihatan, pendidikan, pengetahuan, agama dan keterampilan, pekerjaan, keamanan, bebas dari rasa takut, bebas dari rasa bimbang mahupun kesejahteraannya. Perhatian khusus tersebut berupa perlindungan undangundang dalam mendapatkan hak sivil, hak politik, ekonomi, hak sosial mahupun hak budaya yang lebih baik. ${ }^{17}$

Talcott Parsons dalam teorinya mengemukakan bahawa integrasi sosial ini mengonseptualisasikan masyarakat ideal yang di dalamnya nilai-nilai budaya diinstitusikan dalam sistem sosial, dan individu (sistem keperibadian) akan menuruti jangkaan sosial. Maka, kunci menuju integrasi sosial menurut Parsons adalah proses keseimbangan antara sistem keperibadian, sistem budaya dan sistem sosial. ${ }^{18}$

Merujuk kepada teori di atas, dengan adanya keseimbangan sistem, kedudukan anak nikah sirri tersebut tetap mendapat pengiktirafan, perlindungan dan keadilan sebagaimana peruntukan di bawah Pasal 28D ayat (1) UndangUndang Dasar RI Tahun 1945. Walau bagaimanapun, perlindungan undang-

16 M. Anshary MK, Kedudukan Anak dalam Perspektif Hukum Islam dan Hukum Nasional, 133.

17 H.R. Abdussalam, Hukum Perlindungan Anak (Jakarta: PTIK, 2012), 2.

18 Ritzer George \& Douglas J. Goodman, Teori Sosiologi Modern, 280-281. 
undang yang diberikan kepadanya adalah berbeza jika dibandingkan dengan kedudukan anak dari pernikahan yang sah menurut undang-undang. Hal ini adalah disebabkan kesalahan ibu dan bapanya yang tidak mematuhi undangundang ketika melaksanakan pernikahan. Ketidaksamaan perlindungan undang-undang yang diberikan kepada anak tersebut adalah seperti hak menuntut harta pusaka daripada peninggalan bapanya, oleh sebab hubungan antara anak dengan bapa kandungnya tidak didukung oleh bukti yang sah berupa akta nikah mereka, maka tuntutan harta pusaka tidak dapat difailkan secara rasmi melalui institusi kehakiman. Walau bagaimanapun, dengan merujuk kepada teori Talcott Parsons, mereka tetap berhak menuntut harta pusaka melalui kaedah yang tidak rasmi, umpamanya melalui perbincangan antara ahli keluarga. ${ }^{19}$

\section{KESIMPULAN}

Berdasarkan hasil penelitian yang dihuraikan di atas, terdapat beberapa kesimpulan yang dapat diambil. Pertama, proses pembahagian harta bersama yang diamalkan oleh rumah tangga TKW yang bercerai dari pernikahan sirri di Desa Bunder menggunakan sistem berikut; (a) apabila suami lebih banyak bekerja dan menghasilkan harta berbanding isteri, maka bahagian suami adalah sama besar dengan bahagian isteri dikira dari jumlah aset dalam keluarga, (b) apabila isteri lebih banyak bekerja dan menghasilkan harta berbanding suami, maka bahagian isteri lebih besar berbanding bahagian suami dikira dari jumlah aset dalam keluarga, dan (c) apabila suami atau isteri bekerja menghasilkan jumlah harta yang sama, maka bahagian isteri lebih besar berbanding bahagian suami.

Kedua, kedudukan anak melalui pernikahan secara sirri tetap mendapat pengiktirafan, perlindungan dan kepastian undang-undang yang adil serta perlakuan yang sama di sisi undang-undang, sebagaimana ketentuan Pasal 28D ayat (1) Undang-Undang Dasar Republik Indonesia Tahun 1945.

\section{RUJUKAN}

Abdul Manan, Masalah Hukum Perdata Islam di Indonesia (Jakarta: Kencana, 2006). Cetakan Kedua.

Abdussalam R, Hukum Perlindungan Anak (Jakarta: PTIK, 2012).

Ali Uraidy, MH, 'Perkawinan Sirri dan Akibat Hukumnya Ditinjau Dari Undang-Undang No. 1 Tahun 1974,' Jurnal Ilmiah FENOMENA, vol. 10, no. 2 (2012): 982-998.

$\overline{19}$ Ritzer George $\&$ Douglas J. Goodman, Teori Sosiologi Modern, 144. 
Harta Bersama dan Kedudukan Anak Yang Bercerai Dari Pernikahan Sirri: Kajian Tenaga Kerja Wanita (TKW) di Desa Bunder Kecamatan Susukan Kabupaten Cirebon

Arikunto Suharsimi, Manajemen Penelitian (Jakarta: Rineka Citra, 2005).

Imām al-Shawkān̄̄, Nayl al-Awṭār (Bayrūt: Dār al-Kutub al-‘Alamiyyah, t.t.), Mardani, Hukum Pernikahan Islam di Dunia Islam Modern (Yogjakarta: Graha Ilmu, 2011).

MK M. Anshary, Kedudukan Anak Dalam Perspektif Hukum Islam dan Hukum Nasional (Bandung: CV Mandar Maju, 2014).

Muhammad Abdulkdir, Hukum dan Penelitian Hukum (Bandung: Citra Aditya Bakti, 2004).

Ritzer George \& Douglas J. Goodman, Teori Sosiologi Modern, ed. ke-6 (Jakarta: Kencana Prenada Media Group, 2011).

Soerjono Soekanto, Pengantar Penelitian Hukum (Jakarta: UI Press, 2010).

Sri Sutanti Indriyani, Sosiologi Suatu Kajian Hidup Bermasyarakat (Sukoharjo: Ghalia Indonesia, 2007).

Wahyono Darmabrata, Tinjauan UU No. 1 Tahun 1974 (Gitama Jaya, Jakarta, 2003).

Tihami \& Sobari Sahrani, Fikih Munakahat Kajian Fikih Lengkap (Jakarta, Rajawali Pers, 2013). Ct. 3.

\section{Statut}

Undang-Undang Dasar Republik Indonesia Tahun 1945.

Undang-Undang Nomor 1 Tahun 1974 tentang Pernikahan.

Kompilasi Hukum Islam (KHI).

Keputusan Fatwa Majelis Ulama Indonesia Nomor: 4/MUNAS VII/ MUI/8/2005 tentang Pernikahan Beda Agama. 
Jurnal Syariah, Jil. 26, Bil. 3 (2018) 355-368 